\title{
Evaluation of Crowdfunding Effectiveness in Import Substitution of Agricultural Products
}

\author{
Elena Andreevna Vitsko \\ ITMO University \\ Saint Petersburg, Russian Federation \\ vizko@yandex.ru
}

\author{
Iuliia Nikolaevna Zhuzhoma \\ ITMO University \\ Saint Petersburg, Russian Federation \\ 4257650n@gmail.com
}

\begin{abstract}
This article analyses the findings of the research aimed at study of crowdfunding application in agricultural industry subject to priority of this economic activity for import substitution policy. Within the investigation framework theoretical and practical aspects of crowdfunding application in current Russian conditions were studied, as well as crowdsourcing components as a tool of an alternative bank funding were considered. Besides, authors' interpretation of crowdfunding is given and the conclusions concerning more effective application of this tool by small enterprises in agriculture of Russia are provided.

In addition, the projects being implemented on Boomstarter and Planeta.ru online platforms were considered; conclusions and recommendations pertaining expansion of the crowdfunding range in domestic agriculture were made. Cobb-Douglas production function was applied to perform a study to identify contribution of influence effectiveness of main production factors on agricultural output. The resulting linear model of multiple regression showed an increasing effect from the production scale, with an insufficiently high impact of labour resources quantity and scientific and technological progress. The findings allow us to consider crowdfunding one of the tools of alternative financing of agricultural projects for small enterprises and job creation in rural areas.
\end{abstract}

Keywords: import substitution, agriculture, crowdfinancing, crowdfunding, online platforms, financing

\section{INTRODUCTION}

In circumstances where the current economic situationis characterized by the reduced domestic currency rate, tension in relations with the United States and the European Unionreflected by the notorious law "On Countering America's Adversaries through Sanctions Act" (CAATSA) and the bill "On Defending of American Security from the Kremlin Aggression Act" (DASKAA), as well the EU decision at the June meeting of the European Council to prolongthe anti-Russian sanctionsup to January 31, 2020, when foreign credit institutions are limiting funding and acquisition of finished products by domestic enterprises. While Russia is forced to take counter measures, especially urgent is the problem of expanding import substitution policy aimed at replacing imported goods with similar goods of Russian production.

The domestic economy faced the need to implement measures of the import substitution program as early as in 2012 , thus the import substitution program was developed for the period until 2020 aimed at supporting agricultural production, manufacturing industries, in particular mechanical engineering (production of machinery and equipment), pharmaceuticals (production of medicines and materials used for medical purposes) and the production of computers, electronics, optics, construction (housing), etc.

Implementation of the planned activities within the program requires fairly substantial financial investments from the state provided directly (i.e. subsidies, grants, preferences) and indirectly by involving financial and credit institutions providing with funds on preferential basis within the state support program for these enterprises, or rather business entities engaged in the program.

At the same time, the main issue is that the risks of financial institutions are too high in reality [1,2]. Therefore, the issue of developing alternative tools within financing economic entities, participating in the import substitution program and relating, due to their economic activity type, to the program priority directions, becomes quite crucial. One of the program priorities is agriculture, thus its development and production of import-substituting goods funded by non-bank sources is becoming an extremely relevant issue for discussion [3].

\section{RESEARCH Methodology}

The paper applies a comprehensive approach to efficiency assessment of alternative financing tools of agricultural entities based on application of economic and statistical methods as well as general scientific dialectical methods (analysis, synthesis, specification, generalization, systematic and comprehensive approach), as well as the laws and principles of formal logic. The conducted research and recommendations were carried out on the basis of projects of Boomstarter and Planeta.ru online platforms. 
To conduct the study aimed at identifying contribution of impact effectiveness of main production factors on agriculture output in the Russian Federation, econometric modelling tools were applied as the methodological basis, in particular the Cobb-Douglas production function.

\section{DISCUSSION AND RESULTS}

In the current economic conditions small and medium enterprises (SMEs) play a significant role and are a highly promising sector in the domestic economy, therefore the Decree "On the national goals and strategic objectives of the development of the Russian Federation for the period up to 2024" stipulates that by 2024 it is necessary to increase the number of employees in small and medium agricultural enterprises (including individual entrepreneurs) up to 25 million people, while increasing its share of GDP (GrossDomesticProduct) to $40 \%$ with increase in total volume of non-oil exports to $10 \%$. As part of the agricultural industry, the planned increase in agricultural sector by 2020 is expected to reach 14000 farms, with the increase in agricultural production by the indicated year amounting to $7.4 \%$.

According to the Unified Register of Small and Mediumsized Enterprises for the first half of 2019, the number of SMEs amounted to 6212137 enterprises, the number of agricultural enterprises amounted to 170687 enterprises, including micro-enterprises numbering 161350 , small enterprises -7715 , medium-sized enterprises - 1622 ; legal entities - 44 383, with 126304 enterprises run by individual entrepreneurs. In July 2018, the number of SMEs amounted to 6269150 enterprises, the number of agricultural enterprises amounted to 141632 enterprises, of which micro-enterprises 132 610, small - 7 717, medium-sized enterprises - 1 505; legal entities-39 267, and 102365 enterprises run by individual entrepreneurs. Thus, the data show that the share of agricultural enterprises in the total SMEs number in the first half of this year increased compared to the same period of the previous year and amounted to $2.7 \%$ [4].

In the current circumstances, focusing on implementationof government support of the priority directions, i.e. SME sector development including agricultural business entities, the program "Technical and technological modernization and innovative development" developed for 2013-2020 within the State program of agriculture development and regulation of agricultural products markets, raw materials and food, demonstrates some positive trends for technological upgrading of agricultural machinery and machine-building, livestock breeding and elite crop planting, application of advanced agricultural production technologies, etc. Besides, it shows positive trends in solution of employment issues and, as a result, reduction of human resources outflow from rural areas as well as improving infrastructure development, etc.

However, as noted by Russian economists such as Filimonova N.G., Ozerova M.G., Ermakova I.N. et al. [5], no significant investment processes have been observed so far, although due to state support for subsidizing bank interest the availability of credit resources at a relatively low interest rate from $1 \%$ to $5 \%$ per annum has resulted in significant changes that increase bank financing share in working capital. In 2018, the number of contracts increased by 15.9 thousand contracts compared to 2017, with an increase to 1123.8 billion rubles in monetary terms. As of March 2019, only $10.6 \%$ of state subsidies for the loans issued by financial institutions in the amount of 145.5 billion rubles were distributed [6].

At the same time, it should be pointed out that the main credit institutions approved by the Ministry of Agriculture of the Russian Federation, providing services to farmers, are JSC "Rosselkhozbank" and PJSC "Sberbank", accounting for about $80 \%$ of loans to the agricultural sector [6]. Thus, it can be stated that there is an insufficiently developed conjuncture of credit services to farmers by the banking sector. Therefore, the introduction of alternative tools of fundingthe industry of financial technologies or non-bank lending tools becomes extremely relevant. Such tools include crowdsourcing defined by the authors as collective financing through the use of the Internet resources to meet private and public needs. When considering crowdsourcing, it is possible to identify its main elements as crowdlending, crowdfunding and crowdinvesting.

As part of the study, it can be concluded that domestic legal practice does not provide a clear distinction and does not identify specific features of the considered elements, this also concerns the Federal Law No.259-FZ "On attracting investment by means of investment platforms and on amendments to certain legislative acts of the Russian Federation" as of August 2, 2019, which will be enforced on January 1, 2020, while economic practice tends to confuse the aforesaid concepts frequently.

Therefore, the authors suggest the following interpretation of these concepts:

- crowdlending (or peer-to-peer financing) - peer-to-peer funding through the use of the Internet resources to meet private and public needs on a reimbursable basis;

- crowdfunding - financing through the use of the Internet resources to meet private and public needs, which has a charitable or conditional-return nature of the received resources;

- crowdinvesting - financing through the use of the Internet resources to meet private and public needs by acquiring a share of capital in exchange for investments or income without participation in the capital.

In the course of the study, the authors have come to the conclusion that in general it is possible to use all the abovementioned elements of crowdsourcing in agriculture. As for the development of agricultural SMEs within the import substitution program, in this case due to its specific features, crowdfunding will be the most widely used approach [7]. This is accounted for by the fact that crowdfunding by its economic nature has a conditional-return character, in addition, unlike other elements of crowdsourcing, it directly interacts with fundraising and tends to have a social character, or may be aimed at implementation of socially significant and moral functions [8]. For instance, jobs creation in rural areas $[9,10]$. 
are considered almost unique on the above-mentioned domestic online platforms.

TABLE I. INDICATORS CHARACTERIZING FINANCING OF CROWDFUNDING PROJECTS, BOOMSTARTER AND PLANETA.RU (11], was actually aimed at supporting and developing creative projects. In Russia, within crowdfunding, agricultural projects are mainly implemented by two major online platforms,i.e. Boomstarter and Planeta.ru. Online projects on Boomstarter are especially successful: in 2015, the so-called "ongoing" project (in 2014"Cream-honey with berries. Apiary equipment", which was planned to gather 150 thousand rubles and gathered 454.8 thousand rubles) "Cocco bello honey", production of creamhoney with berries and herbal tea in a nearly extinct village of Maly Turysh gathered 1266.9 thousand rubles, in 2015 the projects of Miron Dementiev's "Restoring "Belye rosy"(White dew) farm" and "Developing "Belye rosy" (White dew) farm", which gathered 455.5 thousand rubles and 915.7 thousand respectively. At the same time, the project "Employment on "Belye rosy" (White dew) farm" wasthe continuation of these projects within the social policy.

The project analysis reveals that duringthe period from 2014 to present the Boomstarter online platform,the year 2016 was the most active one concerning the number and the sumof projects in the agricultural sector, although there was an increase in the total project funding and project funding of the agricultural sector platform more than 1.5 times compared to the previous year.

In 2017, Boomstarter successfully implemented the "Developing Voskresensk Farm" project (as a continuation of the "Farming Revival in Voskresensk" project in 2016) and raised 705.6 thousand rubles. At the moment Boomstarter is implementing current projects - "Nuts and Fruits in People's Gardens" and "Kitchen Garden all the Year Round - Solar Eco-bio-vegetarium " - worth 1400 thousand rubles and 2100 thousand rubles respectively.

Analysis of the projects being implemented on Planeta.ru online platform showed that similarly to Boomstarter the total amount of projects funding has a certain trend to increase. According to the site as early as this February, fundraising amount already exceeded 1 billion rubles. High activity in agricultural projects financing is observed in 2017, especially in "Social Entrepreneurship" and "Business" project categories. In 2018 Planeta.ru supported "Eco-farm in Arkhangelsk Region", "Crowdfunding - the Apiary projects", etc.

The data presented in Table 1 confirm crowdfunding growth in Russian economic practice. At the same time, by 2018 , there was a decrease in the total amount of agricultural projects financing and, consequently, the proportion of agricultural projects implemented on the platforms in the total amount of project financing.

First of all, this is due to certain specific features of such economic activity, i.e. most agricultural products require long production cycle, besides, it should be kept in mind that agriculture belongs to seasonal industries. Therefore, such projects as "Revival of Traditional Horse Breeding" projects related to the Voskresensky Farm implemented in 2016-2017

\begin{tabular}{|c|c|c|c|c|c|}
\hline \multirow{2}{*}{ Index name } & \multicolumn{5}{|c|}{ Period } \\
\hline & 2014 & 2015 & 2016 & 2017 & 2018 \\
\hline $\begin{array}{l}\text { total amount of } \\
\text { funding for } \\
\text { Boomstarter } \\
\text { projects, } \\
\text { thousand rubles }\end{array}$ & 53251.5 & 91135 & 140000 & 213400 & 419000 \\
\hline $\begin{array}{l}\text { total amount of } \\
\text { funding for } \\
\text { Planeta.ru } \\
\text { projects, } \\
\text { thousand rubles }\end{array}$ & 134000 & 179000 & 274100 & 472100 & 940000 \\
\hline $\begin{array}{l}\text { total amount of } \\
\text { funding for AIC } \\
\text { (Agro-Industrial } \\
\text { Complex) } \\
\text { Boomstarter } \\
\text { projects, } \\
\text { thousand rubles }\end{array}$ & 1113.8 & 3697.2 & 6156.8 & 1406 & - \\
\hline $\begin{array}{l}\text { total amount of } \\
\text { funding for AIC } \\
\text { Planeta.ru } \\
\text { projects, } \\
\text { thousand rubles }\end{array}$ & - & 82.3 & 243.3 & 976 & 452.9 \\
\hline $\begin{array}{l}\text { share of AIC } \\
\text { projects } \\
\text { implemented on } \\
\text { Boomstarter in } \\
\text { the total funding } \\
\text { of Boomstarter } \\
\text { projects, \% }\end{array}$ & 2.1 & 4.1 & 4.4 & 0.7 & - \\
\hline $\begin{array}{l}\text { share of AIC } \\
\text { projects } \\
\text { implemented on } \\
\text { Planeta.ru, in the } \\
\text { total funding of } \\
\text { Planeta.ru } \\
\text { projects, \% }\end{array}$ & - & 0.0 & 0.1 & 0.2 & 0.0 \\
\hline
\end{tabular}

${ }^{\text {a. }}$ Source: the calculations have been performed by the authors on the review of crowdfunding sites basis

Projects related to food production, beverage production, delivery of ready meals (healthy food and beverages), setting up restaurants and cafes, trade in farm goods, etc. are popular. Thus, based on the above, it can be concluded that many successful projects only indirectly relate to agriculture, since materials used for production and trade in these projects are usually purchased from farms, and according to OKVED-2 (Russian Classification of Economic Activities) these projects relate either to section $\mathrm{C}$. Manufacturing (food production, beverage production), or to section I. Activities of hotels and catering enterprises (Activities for the provision of food and beverages), or to section G. Wholesale and Retail Trade; repair of motor vehicles and motorcycles (retail trade, except for trade in motor vehicles and motorcycles). The analysis showed that the amount of investments in these projects is directly proportional to the number of successful financed projects. In this regard, measures are urgently required to increase attractiveness of this economic sector, one of the main measures is provision with tax incentives for investors in online projects. Moreover, a special online platform under the 
auspices of the Department of Digital Development and Management of State Information Resources of AIC is essential in agricultural industry rather than anywhere else.

Comparing funds attraction by the Russian and foreign online platforms, it can be noted that as soon as the domestic market began to actively use crowdfunding, i.e. in 2014, Edyn project concerning monitoring of soil and air composition raised 384 thousand dollars on the Kickstarter platform [12] in the same year [13]. In February 2015 the Flow Hive project, the so-called "streaming" hive was launched on the American platform Indiegogo, with the Australian project inventors' raising 12 million dollars instead of the expected 70 thousand dollars [14].

From the foregoing it can be concluded that crowdfunding by its very nature is essential for small businesses, since participating in organization of farming activities and job creation in rural areas, investors focused on income generation in form of agricultural produce, recreation centres in a particular area, etc. The conducted research testifies to the fact that this sector of economic activity urgently requires investments in human resources [15]. Cobb-Douglas function was applied in the study, as this function shows the dependence of production volume on labour costs and fixed capital.

In analysis the following assumptions are taken: in this case the focus is the function parameters that affect the final result, namely, the labour resources number and the fixed capital amount, while such factors as changes in scientific and technological progress, factors related to land resources management, etc. can be ignored.

The resultant two-factor linear model of multiple regression calculated on the basis of table 2 data with application of the least squares method has the form: $\ln (\mathrm{y})=-$ $2.69+1.05 \ln (\mathrm{K})+0.09 \ln (\mathrm{L})$.

TABLE II. INDICES FOR CALCULATION OF THE COBB-DOUGLAS PRODUCTION FUNCTION OF THE RUSSIAN FEDERATION AGRICULTURAL INDUSTRY

\begin{tabular}{|c|c|c|c|}
\hline Year & $\begin{array}{c}\text { GDP (in } \\
\text { comparable } \\
\text { prices), in rubles }\end{array}$ & $\begin{array}{c}\text { Fixed capital (in } \\
\text { comparable } \\
\text { prices), in rubles }\end{array}$ & $\begin{array}{c}\text { Number of } \\
\text { labour } \\
\text { resources, } \\
\text { people }\end{array}$ \\
\hline 2009 & 2639100000000 & 2279914900000 & 6000000 \\
\hline 2010 & 2231603300000 & 2597804000000 & 6000000 \\
\hline 2011 & 3182994000000 & 2911480000000 & 5900000 \\
\hline 2012 & 3105138400000 & 3177032000000 & 5900000 \\
\hline 2013 & 3547611000000 & 3408370000000 & 5800000 \\
\hline 2014 & 3931059600000 & 3741768000000 & 5700000 \\
\hline 2015 & 4335465600000 & 3979400000000 & 5700000 \\
\hline 2016 & 5024740800000 & 4374985000000 & 5276000 \\
\hline 2017 & 5260556700000 & 5008500000000 & 5048600 \\
\hline 2018 & 5078843000000 & 5201200000000 & 4830700 \\
\hline
\end{tabular}

b. Source: the calculations have been performed by the authors on the basis of a review of the data of the State Statistics Committee of the Russian Federation

Mathematical and statistical interpretation of the obtained data looks as follows: multiple determination coefficient $\mathrm{R}^{2}$ $=0.91$, which confirms the relevance of the factors inclusion in the model; the estimated value of F-Fisher criterion - 35.01 exceeds critical -4.74 (with $\alpha=0.05$ ), which also attests to the $\mathrm{R}^{2}$ relevance and the adequacy of the constructed regression equations for the studied process; considering the small sample range, the average approximation error equals $6.25 \%$, which means high adequacy of the developed equations; the calculated values of Student's t-test showed that the value of the t-test of coefficient $a_{1}$ is 3.57 (the tabular value is 2.36 (with $\alpha=0.05)$ ), i.e. inequality $\left|t_{\text {as } 1}\right|>\left|t_{c r}\right|$ is feasible, as regards the criteria $a_{0}$ and $a_{2}$, they are somewhat lower than critical, which indicates the insufficiency of their dynamics. Hence the obtained regression equation:
$\hat{y}=0.07 \cdot \mathrm{K}^{1.05} \cdot \mathrm{L}^{0.09}$.

The sum of the coefficients $a_{1}$ and $a_{2}$ is greater than 1, i.e. there is an increasing effect from production scale. At the same time, the elasticity index in fixed capital significantly exceeds the elasticity index in the labour resources number, i.e. Russian agricultural sector is characterized by laboursaving GDP growth. During the analysed period, the increase in agricultural output was due to the fixed capital growth rather than changes in labour resources number and scientific and technological progress.

\section{CONCLUSION}

Thus, based on the study findings it is possible to consider the emerging trend for the formalized organization of investors' funding in innovative agricultural industry and infrastructure reconstruction by means of crowdfunding. Besides, due to the rather specific nature of crowdfunding and its interaction with fundraising it is possible to reduce some acute problems in agricultural sector related to produce supply to the final consumer, population outflow from rural areas caused by hard physical labour typical for this activity, as well as other unresolved issuessuch as provision of housing, jobs, social services and recreation.

\section{CONFLICT OF INTEREST NOTIFACATION}

We, the authors of this article, bindingly and explicitly declare of the partial and total lack of actual or potential conflict of interest with any other third party whatsoever, which may arise as a result of the publication of this article. This statement relates to the study performance, data collection and interpretation, writing and preparation of the article, and the decision to submit the manuscript for publication.

\section{References}

[1] R. Shaidullin, E. Bulatova, L. Kurmanova, R. Khabibullin and J. Zhuzhoma, "Evaluation of financial stability of Russian companies", E3S Web of Conferences, vol. 110, pp. 02044, 2019. DOI: 10.1051/e3sconf/201911002044.

[2] E.A. Vitsko, "The evolution of commercial and bank credits interaction in domestic economy and enterprise", Economics and Environmental Management, Scientific journal NRU ITMO Series, 1 (16), pp. 23-34, 2014.

[3] V.F. Bashmachnikov, V.V. Drokin, and A.S. Zhuravlev, "Involvement of Rural Housholds in Solving the Problems of Import Substitution", Ekonomika regiona, Economy of Region, 14 (2), pp. 663-675, 2018. DOI: $10.17059 / 2018-2-26$. 
[4] Statistics, Unified register of small and medium-sized businesses $\begin{array}{lcc}\text { [Electronic } & \text { resource]. } & \text { Available } \\ \text { https://rmsp.nalog.ru/statistics.html (Accessed: October 2019). }\end{array}$

[5] N.G. Filimonova, M.G. Ozerova, and I.N. Ermakova, "A crowdfunding model for agricultural financing: Application features", Finance and Credit, vol. 23, iss. 42, pp. 2523-2537, 2017. DOI: 10.24891/fc. 23.42.2523.

[6] Efficiency of preferential crediting of agricultural producers of agroindustrial complex (on the basis of survey) [Electronic resource]. Available https://nifi.ru/images/FILES/NEWS/2019/surveyresult.pdf.

[7] L. Khodov, "How start-ups in Germany are financed?", Sovremennaja Evropa, 5, pp. 86-92, 2017.

[8] E. V. Popov, "Econotronics. Ekonomika regiona", Economy of Region, 14 (1), pp. 13-28, 2018. DOI: 10.17059/2018-1-2.

[9] A. Klychova, G. Klychova, A. Zakirova, R. Sungatullina, K. Mukhamedzyanov, E. Philippova, "Social development mechanism of an agricultural enterprise formation", E3S Web of Conferences, 110, 02072, 2019. DOI: 10.1051/e3sconf/201911002072.
[10] V. Lez'er, N. Semerianova, A. Kopytova, and Y. Truntsevsky, "Youth entrepreneurship as a basis for sustainable urban development: social and legal aspect", E3S Web of Conferences, 110, 02093, 2019. DOI: 10.1051/e3sconf/201911002093.

[11] J.H. Falk and L.D. Dierking, "Re-envisioning Success in the Cultural Sector", Cultural Trends, vol. 17, iss. 42, pp. 233-246, 2008.

[12] V. Kuppuswamy and B.L. Bayus, "Crowdfunding creative ideas: thedynamics of project backers in kickstarter", UNC Kenan-Flagler Research Paper, 15, 2013.

[13] E. Mollick, "The Dynamics of Crowdfunding: Determinants of Success and Failure", Journal of business Venturing, 29, pp. 1-16, 2013.

[14] Market review, Canada Media Fund [Electronic resource]. Available at: http://crowdfunding.cmffmc.ca/ facts_and_stats/market-overview (Accessed: October 2019).

[15] S.N. Pshenichnikova, Structure of economic system: a role of labour. SPb.: Kultinformpress publishing house, 469 p., 2017. 